\title{
FACTORS AFFECTING SATISFACTION AND TURNOVER OF INFORMATION TECHNOLOGY WORKERS IN INDIA
}

\author{
Munish ${ }^{1}$ and Rachna Agarwal ${ }^{2}$ \\ ${ }^{1}$ Assistant Professor, Aravali College of Engineering \& Management, Faridabad, India \\ ${ }^{2}$ Associate professor, YMCA University of Science and Technology, Faridabad, India
}

\begin{abstract}
The current study examined the key factors that influenced the management of knowledge workers in Indian Information Technology sector. This article also ascertained the various practices employed by the employer's and explored the practices which were highly appreciated by the employees and their impact on the knowledge workers management. The collection of data done through a self-administered questionnaire with the help of convenience sampling. The sample size was 500 knowledge workers from 10 IT organizations in Delhi/NCR region. The reliability of the questionnaire was determined by the Cronbach's alpha method and the value for all the variable was greater than 0.7 that acceptable. The analysis of collected data was done through descriptive tests in SPSS and structure equation modelling conducted in AMOS. The results of the study stated that awareness of employer, reward, recognition \& growth, work policies \& arrangement and employer's concern \& care were highly correlated with the knowledge workers management in Indian IT sector.
\end{abstract}

\section{KEYWORDS}

knowledge workers, Indian IT sector, Retention Strategies

\section{INTRODUCION}

The major concern to any business organization is to grow and sustain the level of success for longer periods of time for achieving the competitive edge level. So it's become important to hold the knowledge workers for maintain the level of their expertise and align that with organizational goals. This was earlier cited by the management guru Drucker. He emphasize the importance of work place with the blend of knowledge and knowledge workers. He said knowledge workers apply themselves so strategically with clear concepts and ideas to archive growth.

A study concluded that if a knowledge worker leaves the organization the knowledge also leaves with him which surely hinder the success of an organization ${ }^{[1]}$. Author analyze that all the organization threatens about the risk of losing the knowledge and knowledge workers due to insufficient salary structures, retirements and attritions, amalgamations transfers etc will cause the organization to go big and achieve the level of productivity ${ }^{[2]}$. Authors stated that in order to get the edge on the competition and better level of productivity and get maximum outputs with good margins is only possible when knowledge and knowledge worker retains for longer periods of time and apply themselves to achieve the desire results due to his expertise. So talent retaining becomes vital for any organization they also suggested that management of knowledge is the key DOI :10.14810/ijbbr.2016.5401 
to get over the competition and achieve the goals of the organization. So every possible move has to be exercised to retain the key employees and their expertise if this becomes possible it will serve as an asset to the company ${ }^{[3]}$. The authors concluded in their study that knowledge work leads to better understanding of goals and apply better practices and create a sense of belongingness ${ }^{[4]}$. A study conducted by Boston consulting group speculated that in the USA and world-wide will be a shortage of about 60.5 million skilled workers by the year 2020 that will includes a shortage of knowledge workers of around 17 million in USA alone ${ }^{[5]}$.

\subsection{KNOWLEDGE WORKERS}

Authors stated in their study knowledge workers are the vital ingredients which increases the growth \& efficiency of knowledge innovation \& spreading it. This would be helpful for the growth of the organization ${ }^{[6]}$. Horowitz defines knowledge workers are those workers who have the mastery \& competency in their own area \& high awareness \& having capability to notice, merge \& explain data \& information to make good solutions \& give good solutions for the organization ${ }^{[7}$. The author considers knowledge workers are those workers who opt knowledge from regular education to grow new results $\&$ need to develop regularlyand suggested that good human resource policies and activities always has a positive impact on the retention level of knowledge workers. The suggested that the policy makers should make flexible and competent work policies along with the environment for workers so that autonomy in work can be enhanced $^{[8]}$. A paper defines that these employees are those who have level of competencies, pedagogy \& practical knowledge, and their main aim is to participate in the innovation ${ }^{[9]}$. A research postulated that rewards and Payments plays a crucial role in job satisfaction and keep knowledge workers retain for long ${ }^{[10]}$. The authors showed that knowledge workers use their knowledge as a resource to perform rather than the resources owned by the organization itself ${ }^{[11]}$.

\subsection{KNOWLEDGe Workers In CURRENT Age}

The term knowledge worker was firstly used by Drucker he stated that in 21 st century the key assets will be the knowledge and knowledge workers ${ }^{[12]}$. A study postulated that knowledge workers grows naturally so conducive environment will serve them to grow and achieve higher level of specializations with the data use as the food for them ${ }^{[13]}$. The author analyzed that there is a strong relationship between innovation, knowledge and knowledge workers. Knowledge workers participate in sharing of knowledge across the colleagues, bosses and beyond the boundaries ${ }^{[14]}$. A study stated that as the advancement to the 21 st century and their model of business doing the key area will be knowledge workers and the knowledge work $^{[15]}$. The authors stated in their study that organizations should incorporate retention policies as the primary ones because in recruitment and training organizations invests heavily in the key talents so shortage of the skilled employees leads to critical business cycles so must handle strategically ${ }^{[16]}$.

\subsection{INDIAN INFORMATION TECHNOLOGY INDUSTRY}

The main body of Indian Information Technology industry National Association of Software and Services Companies (Nasscom) predicts that the Indian IT sector will grow by $12-15 \%$ in the upcoming 2017. India is the huge sourcing place for the (IT) industry counted to nearby 67 per cent of the US\$ 124-130 billion market. The industry recruits about 10 million workforces. For the most part the industry has guide the economic change of the country \& convert the recognition of India in the international economy. India's cost competition era supply IT sectors which is approximate which is approximate 3-4 times cheaper than the USA. The software 
industry has also generate relevant requirement in the Indian learning sector mainly for engineering and computer science. The Indian software industry is segmented into four major parts IT services, Business Process Management (BPM), software products and engineering services, and hardware. The IT-BPM sector which is right now c valued at US\$ 143 billion is wish to increase at a Compound Annual Growth Rate (CAGR) of 8.3 per cent year-on-year to US\$ 143 billion for 2015-2016.The part is wish to grant 9.5 per cent of India's Gross Domestic Product (GDP) and more than 45 per cent in total services export in 2015-2016.

\subsection{Connection Between Motivation And Commitment Level On Employee AtTRition}

Employees leaves the organization due to dissatisfaction of policies and their framework. The behavior of the immediate boos affects the level of motivation and the commitment level of the employees in the organization. If an employee experiences good support from the supervisor, good leave policies, competent salary structures, better opportunities to grow, rewards \& recognition, equity in the dealing induce the workers to perform well. The job assignments, ease of doing, expert advice helps the key talent to retain them in the organization for longer periods of time. If an employee is motivated and highly committed it certainly reduce the level of attrition.

\section{LITERATURE REVIEW}

The authors conducted the study in china and concluded that fair compensation structure and the level of motivation plays a vital role in retaining knowledge workers for longer times ${ }^{[17]}$. Their study suggested that the level of training programmes is directly associated with retention and management of knowledge workers ${ }^{[18]}$. In their study about the recruitment and retention of employees in Scotland they postulated that working condition, development option, image of the company and their working policies plays a crucial role in retention of employees ${ }^{[19]}$. The research conducted in 2008 by the Perrin about the retention and engagement of talented employees postulated that the top management intentions in interest of employees is the main driver of engagement ${ }^{[20]}$.

Authors had identified 5 factors which induce the satisfaction level were mainly, discipline, promotions, rewards \& recognition, peers and colleagues etc ${ }^{[21]}$. In their study they had conclude that recreational activities and the allowance for the child improves the employee retention ${ }^{[22]}$. They had postulated that talent management is possible with appropriate management policies and work arrangements. Working environment is be conducive for learning and training ${ }^{[23]}$. The researcher stated that work autonomy, loyalty programmes, proper training and development, good motivation sessions, good level of communication channels, proper evaluation and feedbacks will definitely improve the retention level of knowledge workers ${ }^{[24]}$. Conceded that recognition, career prospects, incentives motivates knowledge workers ${ }^{[25]}$. He conclude in his research that policies and activities of Human Resource department plays a vital role in the development of key workers. These activities surely influence the level of commitment and belongingness to the organization which tends them to do good work ${ }^{[26]}$. Concluded that one of the employee attrition reason is lack of proper mentoring and counselling drives $33 \%$ employees to go for another job options ${ }^{[27]}$. The concluded that job commitment, support from peers and colleagues, equity in treatment, opportunities to grow has a significant impact on knowledge worker retention ${ }^{[28]}$. Stated that experience workers are more productive than the younger ones so the level of retention must be achieved ${ }^{[29]}$. 
Authors stated in his research that commitment of key employees, support from the organization, culture of work, autonomy in decisions may lead to better retention of talented work force ${ }^{[30]}$. They analyzed that Knowledge workers focuses on training programmes, tends to have independency, performs specialized work, more socially focused and always to have law and justice in work on the other side the managers go for routine works, payments and promotions and They conclude that in order to maintain the desired level of knowledge workers in the organization the attitude of the management motivates them and leads to retention ${ }^{[31]}$. Authors stated in their study that knowledge work and its management has a positive influence on the mind set of workers. This attachment build up the knowledge gaining and management with in the knowledge workers ${ }^{[32]}$. The authors stated that knowledge worker is a key and vital employee who creates the value to the programme, he is like an asset to the organization and when they leaves the organization the assets also goes with them ${ }^{[33]}$. He suggested that experience of the knowledge worker creates a value and ethics in the system which motivates other to do well ${ }^{[34]}$. They analyzed that the cost is double to hire a new key employee as compare to the retention of previous one. The authors stated thatknowledge workers are the assets to any organization so has to be properly managed for that proper investment in knowledge worker is needed and Concluded that it's becomes very prominent to know the reasons of attrition and the factors which can induce the employee to retain ${ }^{[35]}$. The researcher postulated in his study that HR/OD professionals need to focus on to make effective and efficient policies to attract and retain talent key force within the organization so that shortage and surplus of man power can be taken care of ${ }^{[36]}$.

The authors had showed that effective retention and engagement policies has be implemented and monitored on the same time. Work culture also plays a dominant role in the retention of knowledge workers ${ }^{[37],[38]}$. The author argued that to create a win- win situation the management must align the benefits of the organization to the values of knowledge workers and their development ${ }^{[39]}$. The researcher conclude that without the knowledge workers there is no meaning of the knowledge ${ }^{[40]}$. The authors Postulated in his study that the responsibilities of the family member has a big impact on the retention of talented work force ${ }^{[41]}$. Authors explained that various factors influenced the level of retention of knowledge workers like: work assignment, challenges in the work, autonomy, pay structures, participation in management and level of job security ${ }^{[42]}$. The author conclude in his study that due to poor infringe benefits knowledge workers tends to move from the organization on regular basis ${ }^{[43]}$. The author conclude that demographic profile of the employees are vital to retain them so they have to be identified and on the same time the various strategies has to be govern for state that what is important is the identification of different management strategies for the different level of the key talent ${ }^{[44]}$. Authors study stated that employee development culture in an organization have a positive effect on their sustainability and long term of employment ${ }^{[45]}$. The authors concluded that to retain the human capital of the organization rewards and development and growth plays a huge role in retention of them ${ }^{[46]}$. The author sated in a study that knowledge worker can deliver or use of talent and with the come up of knowledge base work of knowledge worker become a key that can extract the knowledge and the work together to achieve desired level of outcomes ${ }^{[47]}$. Study conducted by the author stated that demographic profiles must be managed strategically for retention of knowledge workers ${ }^{[48]}$.

\section{Purpose Of The Study}

The objective of the study is identified the factors which influence the management of knowledge workers in Indian IT industry. 


\section{RESEARCH METHODOLOGY}

In the research study, the primary data is collected from the employees working with different IT companies is collected in order to study their perception towards different statement related to Knowledge Workers practices. The data is collected with the help of self-designed questionnaire which was further validated. The data was collected through a self- administered questionnaire consist various demographic profiles of the respondent and 18 questions those were based on 7 point Likert scale where $7=$ Entirely Agree, $6=$ Mostly Agree, $5=$ Agree, $4=$ Neutral, $3=$ Disagree, 2 = Mostly Disagree, $1=$ Entirely Disagree. The questionnaires distributed among respondent were 620 but questionnaire returned back were 500. The respondents were performing the role of software engineers, software developers, IT managers, System engineers and System administrator's from 10 IT organizations in Delhi/NCR region. Sampling adequacy was judged with the help of cronbach's alpha test and was higher than 0.7 for all the statements that is acceptable. Descriptive test were performed to describe and summarize the sample in the SPSS software was used. Factor analysis has been used to define variability and explain the relationship among variables in the study. For model fit the AMOS was used in the study for structure equation modelling to observe the latent variables with help of observed variables.

\section{DATA ANALYSIS \& INTERPRETATION}

\subsection{Factors Affecting KW Management Practices}

In order to measure different aspects of knowledge worker management practices adopted by IT companies in India. Eighteen statements related to different knowledge worker management practices adopted by different IT companies in India are included in the questionnaire. In order to analyze and explore the latent variables, exploratory factor analysis (EFA) statistical method is applied. The EFA helps in identifying the correlation relationship among the variable considered for the study. The Kaiser-Meyer-Olkin Measure (KMO) as well as Bartlett's test of Sphericity is applied in the study in order to test the presence of required sampling adequacy and the correlation structure between different pair of variables. The statistical result of KMO measures of sampling adequacy and Bartlett test of Sphericity is shown below in Table 1.

Table 1. KMO and Bartlett's Test

\begin{tabular}{|l|l|r|}
\hline \multicolumn{2}{|l|}{ Kaiser-Meyer-Olkin Measure of Sampling Adequacy. } & .916 \\
\hline \multirow{3}{*}{ Bartlett's Test of Sphericity } & Approx. Chi-Square & 6595.153 \\
\cline { 2 - 3 } & df & 153 \\
\cline { 2 - 3 } & Sig. & .000 \\
\hline
\end{tabular}

The statistical result of KMO test indicates that the KMO statistic is found to be 0.916 which indicates the presence of required sampling adequacy in the data set collected in the study. The Bartlett's test of Sphericity indicates the existence of significant correlation relationship between the different pair of statements selected for factor analysis. The results of Bartlett test indicate that $\mathrm{p}$ value of Chi-square statistic is found to be less than 5 percent level of significance. 
Table 2 represents the communalities of included statements before and after the factor extraction. The initial communality (before extraction) is always assumed to be 1 . The communality of the variable as shown in the table 2 . indicates the proportion of variance explained by the variables after extraction by factor analysis.

Table 2. Initial and extracted communalities of variables under study

\begin{tabular}{|c|c|c|}
\hline & $\begin{array}{c}\text { Initia } \\
1\end{array}$ & $\begin{array}{c}\text { Extractio } \\
n\end{array}$ \\
\hline $\begin{array}{l}\text { Company is aware about the contribution of knowledge workers in } \\
\text { achieving organizational goals. }\end{array}$ & 1.000 & 677 \\
\hline $\begin{array}{l}\text { CEO and BOD are actively involved with leadership development } \\
\text { activities of knowledge workers. }\end{array}$ & 1.000 & .720 \\
\hline $\begin{array}{l}\text { Employer is responsive and willing to make changes needed to acquire } \\
\text { new techniques and skills. }\end{array}$ & 1.000 & .686 \\
\hline $\begin{array}{l}\text { Company consistently provides ongoing developmental feedback to } \\
\text { support and encourage knowledge workers. }\end{array}$ & 1.000 & .761 \\
\hline Employer motivates group cohesiveness & 1.000 & .789 \\
\hline $\begin{array}{l}\text { Individual achievements of knowledge workers are recognized and } \\
\text { rewarded by management. }\end{array}$ & 1.000 & .689 \\
\hline $\begin{array}{l}\text { Subjectively measures the knowledge workers on the basis of total } \\
\text { contribution/team efforts and accountable for complex job assignments. }\end{array}$ & 1.000 & .632 \\
\hline $\begin{array}{l}\text { Knowledge workers are motivated and encouraged by the management } \\
\text { to upgrade their current skill set and knowledge. }\end{array}$ & 1.000 & .719 \\
\hline Maximizing the value and potential of knowledge workers. & 1.000 & .760 \\
\hline $\begin{array}{l}\text { Encourages and support knowledge workers to look at lateral roles as a } \\
\text { growth option. }\end{array}$ & 1.000 & .779 \\
\hline $\begin{array}{l}\text { Provides flexible work arrangements for knowledge workers in order to } \\
\text { perform their assigned tasks. }\end{array}$ & 1.000 & .769 \\
\hline $\begin{array}{l}\text { Focused on creative process for knowledge workers to improve } \\
\text { knowledge management and collaborative project. }\end{array}$ & 1.000 & .780 \\
\hline $\begin{array}{l}\text { Organization has right pool of knowledge workers for its present and } \\
\text { future strategies. }\end{array}$ & 1.000 & .810 \\
\hline $\begin{array}{l}\text { New projects are used to address specific leader development needs of } \\
\text { knowledge workers. }\end{array}$ & 1.000 & .808 \\
\hline $\begin{array}{l}\text { Care for well-being of knowledge workers by making their lives easier } \\
\text { and less stress. }\end{array}$ & 1.000 & .771 \\
\hline Viewed the knowledge workers as corporate assets. & 1.000 & .756 \\
\hline $\begin{array}{l}\text { Company is much concern about the career development and growth } \\
\text { opportunities for knowledge workers in future. }\end{array}$ & 1.000 & .819 \\
\hline $\begin{array}{l}\text { Mentoring relationships going on to build motivation and loyalty } \\
\text { among knowledge workers. }\end{array}$ & 1.000 & .786 \\
\hline
\end{tabular}

Extraction Method: Principal Component Analysis. 
The result indicates that the initial communalities of each variable is found to be 1 . However, the extracted communalities are less than 1 . The result indicates that the extracted communalities of all the variables is found to be greater than 0.6. The extracted communalities indicate the goodness of fit of the factor analysis. The results of factor analysis after applying principle component analyses is shown in table 3.

Table 3. Total Variance Explained

\begin{tabular}{|c|c|c|c|c|c|c|c|c|c|}
\hline \multicolumn{9}{|c|}{ Total Variance Explained } \\
\hline \multirow{2}{*}{$\begin{array}{l}\text { Compon } \\
\text { ent }\end{array}$} & \multicolumn{3}{|c|}{ Initial Eigenvalues } & \multicolumn{2}{|c|}{$\begin{array}{c}\text { Extraction Sums of Squared } \\
\text { Loadings }\end{array}$} & \multicolumn{2}{|c|}{$\begin{array}{c}\text { Rotation Sums of Squared } \\
\text { Loadings }\end{array}$} \\
\cline { 2 - 11 } & Total & $\begin{array}{c}\text { \% of } \\
\text { Variance }\end{array}$ & $\begin{array}{c}\text { Cumulati } \\
\text { ve \% }\end{array}$ & Total & $\begin{array}{c}\text { \% of } \\
\text { Variance }\end{array}$ & $\begin{array}{c}\text { Cumulati } \\
\text { ve \% }\end{array}$ & $\begin{array}{c}\text { Total } \\
\text { \% of } \\
\text { Variance }\end{array}$ & $\begin{array}{c}\text { Cumulati } \\
\text { ve \% }\end{array}$ \\
\hline 1 & 9.302 & 51.678 & 51.678 & 9.302 & 51.678 & 51.678 & 3.675 & 20.418 & 20.418 \\
\hline 2 & 1.628 & 9.045 & 60.723 & 1.628 & 9.045 & 60.723 & 3.581 & 19.895 & 40.314 \\
\hline 3 & 1.459 & 8.107 & 68.830 & 1.459 & 8.107 & 68.830 & 3.163 & 17.574 & 57.888 \\
\hline 4 & 1.122 & 6.236 & 75.066 & 1.122 & 6.236 & 75.066 & 3.092 & 17.178 & 75.066 \\
\hline 5 & .503 & 2.793 & 77.859 & & & & & & \\
\hline 6 & .445 & 2.470 & 80.329 & & & & & & \\
\hline 7 & .429 & 2.386 & 82.714 & & & & & & \\
\hline 8 & .409 & 2.273 & 84.987 & & & & & & \\
\hline 9 & .355 & 1.973 & 86.960 & & & & & & \\
\hline 10 & .334 & 1.857 & 88.817 & & & & & & \\
\hline 11 & .320 & 1.779 & 90.596 & & & & & & \\
\hline 12 & .319 & 1.771 & 92.367 & & & & & & \\
\hline 13 & .290 & 1.612 & 93.979 & & & & & & \\
\hline 14 & .276 & 1.536 & 95.515 & & & & & & \\
\hline 15 & .239 & 1.329 & 96.844 & & & & & & \\
\hline 16 & .212 & 1.178 & 98.022 & & & & & & \\
\hline 17 & .190 & 1.057 & 99.079 & & & & & & \\
\hline 18 & .166 & .921 & 100.000 & & & & & & \\
\hline
\end{tabular}

Extraction Method: Principal Component Analysis.

The results indicate that the 18 statements considered for the study can be reduced to 4 principle components having Eigen values more than 1. These 5 factors explain approx. 75 percent of the variance of the included statements. Assuming that the explained variance is sufficient, the extracted factors will be used for further analysis. In order to modify the extracted components representing the 18 statements/variables considered for the study, orthogonal rotation (Varimax) is applied. The rotated component matrix (RCM) represents the factor loading of each variable to the extracted factors. The result of the rotated component matrix is shown below in table no 4 . 
Table 4. Rotated Component Matrix

\begin{tabular}{|c|c|c|c|c|}
\hline & \multicolumn{4}{|c|}{ Component } \\
\hline & 1 & 2 & 3 & 4 \\
\hline $\begin{array}{l}\text { Company is aware about the contribution of knowledge workers in } \\
\text { achieving organizational goals. }\end{array}$ & .728 & .260 & .209 & .190 \\
\hline $\begin{array}{l}\text { CEO and BOD are actively involved with leadership development } \\
\text { activities of knowledge workers. }\end{array}$ & .783 & .171 & .239 & .143 \\
\hline $\begin{array}{l}\text { Employer is responsive and willing to make changes needed to } \\
\text { acquire new techniques and skills. }\end{array}$ & .771 & .184 & .126 & .203 \\
\hline $\begin{array}{l}\text { Company consistently provides ongoing developmental feedback to } \\
\text { support and encourage knowledge workers. }\end{array}$ & .806 & .226 & .190 & .155 \\
\hline Employer motivates group cohesiveness & .751 & .362 & .234 & .200 \\
\hline $\begin{array}{l}\text { Individual achievements of knowledge workers are recognized and } \\
\text { rewarded by management. }\end{array}$ & .348 & .695 & .192 & .220 \\
\hline $\begin{array}{l}\text { Subjectively measures the knowledge workers on the basis of total } \\
\text { contribution/team efforts and accountable for complex job } \\
\text { assignments. }\end{array}$ & .202 & .737 & .157 & .152 \\
\hline $\begin{array}{l}\text { Knowledge workers are motivated and encouraged by the } \\
\text { management to upgrade their current skill set and knowledge. }\end{array}$ & .210 & .785 & .169 & .173 \\
\hline Maximizing the value and potential of knowledge workers. & .261 & .756 & .226 & .262 \\
\hline $\begin{array}{l}\text { Encourages and support knowledge workers to look at lateral roles as } \\
\text { a growth option. }\end{array}$ & .194 & .785 & .185 & .301 \\
\hline $\begin{array}{l}\text { Provides flexible work arrangements for knowledge workers in order } \\
\text { to perform their assigned tasks. }\end{array}$ & .168 & .235 & .198 & .804 \\
\hline $\begin{array}{l}\text { Focused on creative process for knowledge workers to improve } \\
\text { knowledge management and collaborative project. }\end{array}$ & .232 & .227 & .182 & .800 \\
\hline $\begin{array}{l}\text { Organization has right pool of knowledge workers for its present and } \\
\text { future strategies. }\end{array}$ & .220 & .277 & .265 & .784 \\
\hline $\begin{array}{l}\text { New projects are used to address specific leader development needs } \\
\text { of knowledge workers. }\end{array}$ & .211 & .258 & .382 & .742 \\
\hline $\begin{array}{l}\text { Care for well-being of knowledge workers by making their lives } \\
\text { easier and less stress. }\end{array}$ & .254 & .232 & .763 & .268 \\
\hline Viewed the knowledge workers as corporate assets. & .124 & .141 & .822 & .213 \\
\hline $\begin{array}{l}\text { Company is much concern about the career development and growth } \\
\text { opportunities for knowledge workers in future. }\end{array}$ & .305 & .192 & .798 & .229 \\
\hline $\begin{array}{l}\text { Mentoring relationships going on to build motivation and loyalty } \\
\text { among knowledge workers. }\end{array}$ & .254 & .274 & .773 & .219 \\
\hline
\end{tabular}

Extraction Method: Principal Component Analysis. 
Rotation Method: Varimax with Kaiser Normalization

a. Rotation converged in 6 iterations.

The result of rotated component matrix (RCM) indicates that the 18 statements can be reduced to 4 extracted components. It is also observed from the results that the significant factor loadings for each factor is found to be greater than 0.7. Analyzing the variables having significant factor loadings to different factors. These factors can be named in table no. 5 as:

Table 5. List of factors

\begin{tabular}{|l|l|}
\hline Factors & Factor Name \\
\hline 1 & Employer's Awareness \\
\hline 2 & Reward, Recognition and Growth \\
\hline 3 & Work policies and Arrangements \\
\hline 4 & Employer's concern and care \\
\hline
\end{tabular}

These factors are explained below in detail

\section{FACTOR 1: EMPLOYER AWARENESS}

After applying exploratory factor analysis (EFA) it is found that the factor employer awareness consist of five major variables having significant loadings towards the factors. In the study the internal consistency of the factor is estimated with the help of Cronbach's alpha. The statements included in the factor employer's awareness is found to have the internal consistency reliability (as measured by cronbach's alpha) of (0.902) which indicates the presence of sufficient internal consistency reliability in the factor as shown below in table no. 6 .

Table 6. Employer Awareness

\begin{tabular}{|c|c|c|c|c|c|}
\hline Construct & Variables & $\begin{array}{l}\text { Mean } \\
\text { (S.D) }\end{array}$ & Skewness & Kurtosis & $\begin{array}{c}\text { Internal } \\
\text { Consistency } \\
\text { Reliability }\end{array}$ \\
\hline \multirow{5}{*}{$\begin{array}{l}\text { Employer } \\
\text { Awareness }\end{array}$} & $\begin{array}{l}\text { Company is aware about the } \\
\text { contribution of knowledge } \\
\text { workers in achieving } \\
\text { organizational goals. }\end{array}$ & $\begin{array}{c}4.55 \\
(1.52)\end{array}$ & -.401 & -.485 & \multirow{5}{*}{0.902} \\
\hline & $\begin{array}{l}\text { CEO and BOD are actively } \\
\text { involved with leadership } \\
\text { development activities of } \\
\text { knowledge workers. }\end{array}$ & $\begin{array}{c}4.60 \\
(1.49)\end{array}$ & -.440 & -.520 & \\
\hline & $\begin{array}{l}\text { Employer is responsive and } \\
\text { willing to make changes } \\
\text { needed to acquire new } \\
\text { techniques and skills. }\end{array}$ & $\begin{array}{c}4.74 \\
(1.44)\end{array}$ & -.375 & -.601 & \\
\hline & $\begin{array}{lr}\text { Company } & \text { consistently } \\
\text { provides ongoing } \\
\text { developmental feedback to } \\
\text { support and encourage } \\
\text { knowledge workers }\end{array}$ & $\begin{array}{c}4.69 \\
(1.45)\end{array}$ & -.391 & -.508 & \\
\hline & $\begin{array}{l}\text { Employer motivates group } \\
\text { cohesiveness }\end{array}$ & $\begin{array}{c}4.70 \\
(1.35)\end{array}$ & -.370 & -.471 & \\
\hline
\end{tabular}


The results indicates that the statements of the factor "Employers responsiveness and willing to make changes needed to acquire new techniques and skills" is found that to highest (4.74). The lowest score is found in case of statement "Company is aware about the contribution of knowledge workers in achieving organizational goals".

\section{FACTOR 2: REWARDS, RECOGNITION \& GROWTH}

The second factor extracted from EFA is named as "Rewards, Recognition \& Growth". The second factor consist of five major statements as shown in table.no. 7.In the study the internal consistency of the factor is estimated with the help of Cronbach's alpha. The statements included in the factor Rewards, Recognition \& Growth is found to have the internal consistency reliability (as measured by cronbach's alpha) of (0.897) which indicates the presence of sufficient internal consistency reliability in the factors shown below in table no. 7.

Table7. Rewards, Recognition \& Growth

\begin{tabular}{|c|c|c|c|c|c|}
\hline Construct & Variables & $\begin{array}{l}\text { Mean } \\
\text { (S.D) }\end{array}$ & Skewness & Kurtosis & $\begin{array}{l}\text { Internal } \\
\text { Consiste } \\
\text { ncy } \\
\text { Reliabili } \\
\text { ty }\end{array}$ \\
\hline \multirow{5}{*}{$\begin{array}{l}\text { Rewards, } \\
\text { Recognition } \\
\text { \& Growth }\end{array}$} & $\begin{array}{l}\text { Individual achievements of } \\
\text { knowledge workers are recognized } \\
\text { and rewarded by management. }\end{array}$ & $\begin{array}{c}4.55 \\
(1.35)\end{array}$ & -.550 & -.133 & \multirow{5}{*}{$\mathbf{0 . 8 9 7}$} \\
\hline & $\begin{array}{l}\text { Subjectively measures the } \\
\text { knowledge workers on the basis of } \\
\text { total contribution/team efforts and } \\
\text { accountable for complex job } \\
\text { assignments. }\end{array}$ & $\begin{array}{c}4.50 \\
(1.40)\end{array}$ & -.487 & -.225 & \\
\hline & $\begin{array}{l}\text { Knowledge workers are motivated } \\
\text { and encouraged by the } \\
\text { management to upgrade their } \\
\text { current skill set and knowledge. }\end{array}$ & $\begin{array}{c}4.52 \\
(1.41)\end{array}$ & -.277 & -.643 & \\
\hline & $\begin{array}{l}\text { Maximizing the value and potential } \\
\text { of knowledge workers. }\end{array}$ & $\begin{array}{c}4.58 \\
(1.37)\end{array}$ & -.329 & -.587 & \\
\hline & $\begin{array}{l}\text { Encourages and support knowledge } \\
\text { workers to look at lateral roles as a } \\
\text { growth option. }\end{array}$ & $\begin{array}{c}4.54 \\
(1.45)\end{array}$ & -.380 & -.542 & \\
\hline
\end{tabular}

The results indicates that the statements of the factor "Maximizing the value and potential of knowledge workers." is found that to highest (4.58). The lowest score is found in case of statement "Subjectively measures the knowledge workers on the basis of total contribution/team efforts and accountable for complex job assignments".

\section{FaCtor 3: Work Policies \& ARrangements}

The third factor extracted from the factor analysis is Work Policies \& Arrangements. This factor consist of 4 statements. In the level of internal consistency for the factor was determined with the help of Cronbach's alpha test. Work Policies \& Arrangements factor statements werefound internal consistency reliability of $\mathbf{( 0 . 9 0 8 )}$ which state and indicates that internal consistency reliability is sufficient and acceptable in the factor. The descriptive analysis postulated the following analysis of statement as under in table no. 8. 
International Journal of BRIC Business Research (IJBBR) Volume 5, Number 3/4, November 2016

Table 8. Work Policies \& Arrangements

\begin{tabular}{|c|c|c|c|c|c|}
\hline Construct & Variables & $\begin{array}{l}\text { Mean } \\
\text { (S.D) }\end{array}$ & Skewness & Kurtosis & $\begin{array}{c}\text { Internal } \\
\text { Consistency } \\
\text { Reliability }\end{array}$ \\
\hline \multirow{4}{*}{$\begin{array}{c}\text { Work Policies \& } \\
\text { Arrangements }\end{array}$} & $\begin{array}{l}\text { Provides flexible } \\
\text { arrangements for knowledge } \\
\text { workers in order to perform } \\
\text { their assigned tasks. }\end{array}$ & $\begin{array}{c}4.37 \\
(1.58)\end{array}$ & -.478 & -.628 & \multirow{4}{*}{0.908} \\
\hline & $\begin{array}{l}\text { Focused on creative process } \\
\text { for knowledge workers to } \\
\text { improve } \\
\text { management and collaborative } \\
\text { project. }\end{array}$ & $\begin{array}{c}4.41 \\
(1.43)\end{array}$ & -.358 & -.781 & \\
\hline & $\begin{array}{l}\text { Organization has right pool of } \\
\text { knowledge workers for its } \\
\text { present and future strategies. }\end{array}$ & $\begin{array}{c}4.45 \\
(1.47)\end{array}$ & -.376 & -.727 & \\
\hline & $\begin{array}{l}\text { New projects are used to } \\
\text { address specific leader } \\
\text { development needs } \\
\text { knowledge workers. }\end{array}$ & $\begin{array}{c}4.48 \\
(1.50)\end{array}$ & -.365 & -.662 & \\
\hline
\end{tabular}

The results of descriptive study showed that indicates that the factor "New projects are used to address specific leader development needs of knowledge workers." is found that to highest (4.48) and the least was extracted by the statement "Flexible work arrangements for knowledge workers in order to perform their assigned tasks".

\section{FACTOR 4: EMPLOYER' S CONCERN \& CARE}

The fourth factor extracted from the factor analysis is Concern \& Care. 4 variables were studied under this factor. In the level of internal consistency for the factor was calculated with the help of Cronbach's alpha test. Concern \& Care factor statements were found internal consistency reliability of (0.904) which concludes and indicates that internal consistency reliability is significant and acceptable in the factor. The descriptive analysis postulated the following analysis of statement as under in table no. 9.

Table 9. Employer's Concern \& Care

\begin{tabular}{|c|l|c|c|c|c|}
\hline Construct & \multicolumn{1}{|c|}{ Variables } & Mean & Skewness & Kurtosis & $\begin{array}{c}\text { Internal } \\
\text { Consistency } \\
\text { Reliability }\end{array}$ \\
\hline \multirow{5}{*}{$\begin{array}{c}\text { Concern \& } \\
\text { Care }\end{array}$} & $\begin{array}{l}\text { Care for well-being of } \\
\text { knowledge workers by making } \\
\text { their lives easier and less } \\
\text { stress. }\end{array}$ & $\begin{array}{c}4.48 \\
(1.52)\end{array}$ & -.335 & -.683 & \\
\cline { 2 - 5 } & $\begin{array}{l}\text { Viewed the knowledge } \\
\text { workers as corporate assets. }\end{array}$ & $\begin{array}{c}4.55 \\
(1.50)\end{array}$ & -.396 & -.630 & \\
\cline { 2 - 5 } & $\begin{array}{l}\text { Company is much concern } \\
\text { about the career development } \\
\text { and growth opportunities for } \\
\text { knowledge workers in future. }\end{array}$ & $\begin{array}{c}4.60 \\
(1.52)\end{array}$ & -.443 & -.604 & \multirow{2}{*}{$\mathbf{0 . 9 0 4}$} \\
\hline
\end{tabular}




\begin{tabular}{|l|l|c|c|c|c|}
\hline & $\begin{array}{l}\text { Mentoring relationships going } \\
\text { on to build motivation and } \\
\text { loyalty among knowledge } \\
\text { workers. }\end{array}$ & $\begin{array}{c}4.58 \\
\text { (1.56) }\end{array}$ & -.376 & -.585 & \\
\hline
\end{tabular}

The results showed that the factor "Company is much concern about the career development and growth opportunities for knowledge workers in future" is found that to highest (4.60) and the least was extracted by the statement "Care for well-being of knowledge workers by making their lives easier and less stress".

\subsection{VALIDITY ANALYSIS OF THE IDENTIFIEd FACTORS USING CONFIRMATORY FACTOR ANALYSIS (CFA)}

Before applying SEM to achieve the objective it is required to test the construct validity of the identified scale of knowledge worker management practices. Confirmatory factor analysis (hereafter CFA) is used to test the construct validity of the scale developed (in order to measure knowledge worker management practices) in the process of applying EFA. Construct validity which includes both convergent as well as discriminant validity of the construct used in the scale can be tested with the help of CFA. The composite reliability of all the constructs should be greater than 0.7 and average variance extracted should also be greater than $0.5 \mathrm{In}$ order to ensure the presence of discriminant validity the average variance extracted measure of each construct should be greater than average shared variance (ASV) measure as well as maximum shared variance (MSV) measure of each construct. The confirmatory factor analysis is represented by the figure and tables below:

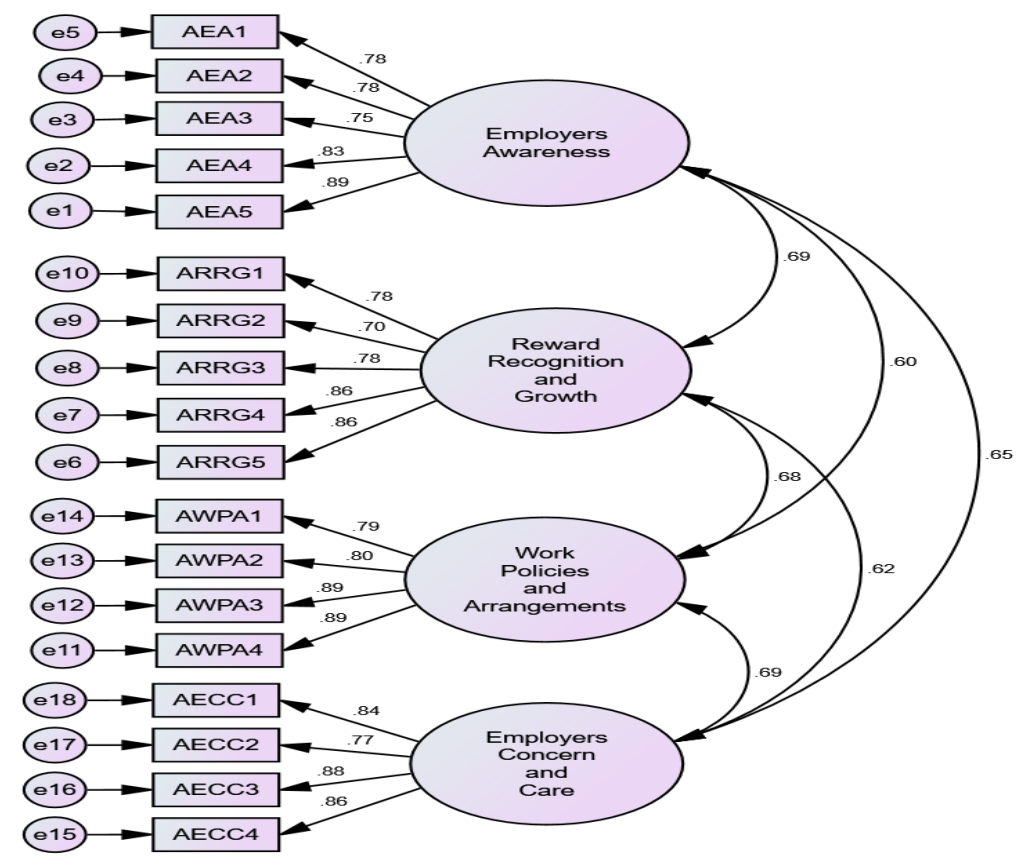

Figure 1. Confirmatory Factor Analysis using AMOS

The table shown below that the composite reliability in case of all the constructs in the study are found to be greater than 0.7. In addition to this the average variance extracted measures of all the constructs are found to be greater than 0.5. Hence it can be concluded from the results of CFA that the constructs used in the study in the measurement have adequate convergent validity. Since 
the construct validity of the scale used in order to measure the knowledge worker management practices in the selected organisations is ensured, the construct can be used in the SEM method to study the impact of knowledge worker management practices in the organisation on the retention and engagements of employees in the organisations.

\subsection{VALIDITY ANALYSIS}

\begin{tabular}{|l|c|c|c|r|r|r|r|r|}
\hline & CR & \multicolumn{1}{|l}{ AVE } & MSV & MaxR(H) & WPA & EA & RRG & ECC \\
\hline WPA & 0.909 & 0.714 & 0.480 & 0.919 & $\mathbf{0 . 8 4 5}$ & & & \\
\hline EA & 0.903 & 0.651 & 0.476 & 0.956 & 0.603 & $\mathbf{0 . 8 0 7}$ & & \\
\hline RRG & 0.898 & 0.640 & 0.476 & 0.969 & 0.681 & 0.690 & $\mathbf{0 . 8 0 0}$ & \\
\hline ECC & 0.905 & 0.704 & 0.480 & 0.977 & 0.693 & 0.646 & 0.620 & $\mathbf{0 . 8 3 9}$ \\
\hline
\end{tabular}

\subsection{MODEL Fit}

\begin{tabular}{|c|c|c|c|c|}
\hline CMIN/DF & GFI & RMR & CFI & RMSEA \\
\hline 2.099 & .942 & .067 & .978 & .047 \\
\hline
\end{tabular}

The table indicates the goodness of fit indices of the measurement model. The fitness indices of the CFA model indicates that the CFA is statistically fit and the different constructs can be used in the SEM further.

\section{RECOMMENDATIONS \& CONCLUSION}

The present study explained about the practices adopted by the top management to retain the key talent. The analysis part explored that employer's awareness, Reward, Recognition and Growth, Work policies and Arrangements and Employer's concern and care drives the level of retention in Indian IT sector up to great extent. From the data analysis it is explored that knowledge workers have to plan and set their career by applying themselves and achieve multilevel skills by continuous training, learning education and research because by the virtue of it they can be regarded as knowledge workers. The present study postulated that in this competitive world knowledge workers become an assets to the company so to manage and trained strategically and must have the power of autonomy in their work and assignments. Organization must think to align their career and development opportunities the success path of the concern. The organizations has to develop and maintain a right pool of knowledge workers by attracting and retain the knowledge workers. The research concluded that contribution of knowledge workers, their prestige, acre and rewards for the good work done motivated them to retain and develop and link the performance with rewards. The current study is focused on the driver which may affect the level of knowledge worker management so academicians must understand the business environment which is so dynamic so the future research should focus on to identify more factors and extract more theories to gain proper insights of the topic.

In current competitive world it's a huge task to manage and retain the knowledge workers. The mobility becomes a critical issues to manage as its results into the loss of knowledge and knowledge workers. The present research concluded the factors which can affect the level of management of knowledge workers in the organization. The result postulated that all the variables studied in the study has a significant factor loadings to each factor and highly correlated with management of knowledge workers. The main antecedents were the awareness of employers 
towards the contribution of the knowledge workers in the organization, development opportunities, training, recognition and rewards for better performance, employer's perception as consider the knowledge workers as corporate assets, concern and care for well-being, flexible work arrangements, selection of groups for projects and assignments etc. The Indian IT sector has experiences the shortage of knowledge workers quite consistently so the top management has to manage the retention and management of these talented workforce strategically by applying various practices which can be tested through research and time. They have to align the career path of the knowledge workers to organizational goals for better productivity level. The level of motivation and commitment of the employee helps the HR professionals to reduce the rate of employee turnover because again it is burden on the organization to recruit more people and train them on the same time so HR managers have to make sure that employees must experiencing a great level of motivation and job engagement all the time.

\section{REFERENCES}

[1] Mohammed Ali et al. (2009). "Measuring Knowledge Retention: A Case Study of a Construction Consultancy in the UAE". Journal of Engineering, Construction and Architectural Management. 16(1): 92-108. Retrieved $01 \quad$ November, 2013 from www.emeraldinsight.com/journals.htm?articleid=1765031.

[2] Levy, M. (2011). Knowledge Retention: Minimizing Organizational Business Loss. Journal of Knowledge Management. Vol. 15 Iss: 4, pp.582 - 600.

[3] Martins, E.L. \& Meyer, Hester W.J. (2012). Organizational and Behavioural Factors that Influence Knowledge Retention. Journal of Knowledge Management. 16(1): 77-96.DOI: 10.1108/13673271211198954

[4] Abdelkader Daghfous, Omar Belkhodja, \& Angell, Linda C. (2013) Understanding and Managing Knowledge Loss. Journal of Knowledge Management. 17 (5): 639-660.

[5] Holland, P., Sheehan, C. \& De Cieri, H. (2007, September). Attracting and retaining talent: Exploring human resources development trends in Australia. Human Resource Development International, 10(3), 247-262.

[6] Rasouli, R., \& Rashid, M. (2015). Define and design a basic knowledge of the maintenance staff. Journal of Human Resource Management, University of Imam Hussein (AS), 7(1), 55-39.

[7] Horwitz, M. (2000). Flexible Work Practices and Human Resource Management. International Journal of Human Resource Management, 9(4).

[8] Martin, M. J. (2011). Influence of Human Resource practices on Employee Intention to Quit (Unpublished Doctoral Dissertation). Faculty of Virginia Polytechnic Institute and State University. Retrieved July, 15, 2011, from https://theses.lib.vt.edu/theses/available/etd-07272011 150612/unrestricted/Martin_MJ_D_2011

[9] Davenport, T. H. (2005). Thinking for a Living: How to Get Better Performance and Results from Knowledge Workers.Boston: Harvard Business School Press. ISBN 1-59139-423-6.

[10] Winterton, J. (2004). A conceptual model of labour turnover and retention. Human Resource Development International, 7(3), 371-390.

[11] Horwitz, F., Teng Heng. C. and Quazi. H.A. (2003). Finders Keepers? Attracting, Motivating and Retaining Knowledge workers, Human Resource Management Journal, 13(4), 23-43.

[12] Drucker, P. F. (1959). The Landmarks of Tomorrow. New York: Harper and Row.

[13] Weiss, Paul A. (1960). "Knowledge a growth process". Science. 130: 1716-1719.Doi: 10.1126/science.131.3415.1716.

[14] Tapscott, Don, Williams, Anthony D. (2006). Wikinomics: How Mass Collaboration Changes Everything. New York: Penguin. ISBN 1-59184-138-0.

[15] Palmer, Nathaniel. (2014). Workers. Future Strategies Inc. ISBN 978-0-984976478.

[16] Chhabra, N. L., \& Mishra, A. (2008). Talent management and employer branding: Retention battle strategies. ICFAI Journal of Management Research, 7(11), 50-61.

[17] Chiu, Randy K., Luk, Vivianne W. \& Tang, Thomas L. (2002). Retaining and Motivating Employees: Compensation Preferences in Hong Kong and China Retrieved December 16, 2012 from http://dx.doi.org/10.1108/00483480210430346. 
[18] Acton, T. \& Golden, W. (2003). Training the Knowledge Worker: A Descriptive Study of Training Practices in Irish Software Companies.Journal of European Industrial Training, Vol. 27 Iss: 2/3/4, pp.137 - 146. http://dx.doi.org/10.1108/03090590310468958

[19] Martin, A., Mactaggart, D. \& Bowden, J. (2006). The Barriers to the Recruitment and Retention of Supervisors/Managers in the Scottish Tourism Industry. Retrieved December 16, 2012 from http://dx.doi.org/10.1108/09596110673529

[20] Doh, J. P., Smith, R. R., Stumpf, S. A. \& Tymon, Jr., W. G. (2011). Pride and professionals: Retaining talent in emerging economies. Journal of Business Strategy, 32(5), 35-42.

[21] Lee-Kelley, L., Blackman, Deborah A. \& Hurst, Jeffrey P. (2007). An Exploration of the Relationship between Learning Organizations and the Retention of Knowledge Workers. Retrieved December 1, 2012 from www.emeraldinsight.com/0969-6474.htm.

[22] Landsman, M. (2007). Supporting Child Welfare Supervisors to Improve Worker Retention. Retrieved December 13, 2012 from http://www.cwla.org/.

[23] Delfgaauw, J., \& Robert, D. (2010). Managerial talent, motivation, and self-selection into public management. Journal of Public Economics, 94(9-10), 654-660.

[24] Shuaib, \& Shandana. (2006). Managing Knowledge Workers. Faculty Member Institute of management Sciences Peshawar (7 / B-3, Phase-V, Hayatabad, Peshawar). Retrieved 21 July, 2016, from http://www.ccsenet.org/journal/index.php/mas/article/viewFile/61598/33065 doi:10.5539/mas.v10n9

[25] Ingo, F., \& Fiona, L. (2007). Cultural differences in motivating global knowledge workers. Equal Opportunities International, 26(8), 823-833. http://dx.doi.org/10.1108/02610150710836154

[26] Chew, J., \& Cheng, L. (2004). The Influence of Human Resource Management Practices on the Retention of Core Employees of Australian Organizations: An Empirical Study (Unpublished Doctoral Dissertation). Murdoch University. Retrieved July, 2004, from https://core.ac.uk/download/pdf/11231292

[27] Aiman Smith, L., Bergey, P., Cantwell, A. R., \& Doran, M. (2006, July-August). The coming knowledge and capability shortage. Research Technology Management, 49(4), and 15.

[28] Price, J., \& Mouler. (2006). Reflection on the determinants of voluntary turnover. International Journal of Manpower, 22(7), 600-624.

[29] Stam, C. (2009). Knowledge and the ageing employee: A research agenda. Proceedings of the European Conference on Intellectual Capital, 435-441.

[30] Chaeichi, \& Airkeyvan. (2015). Check individual and organizational factors influencing the retention of employees in the company spreads eagle (Master's thesis). University anymore.

[31] Gholipour, R., Amiri, A. N., Mehdi, R., Mohammad, R., \& Zamanifar, M. (2013). Identify factors affecting shelf life of knowledge workers in the Iranian Oil Refining and Distribution Company. Journal of Management and Organizational Culture, 11 (II), 161-133.

[32] Mahmoudsalehi, M., \& Moradkhannejad, R. (2012). How Knowledge Management is affected by Organizational Structure. The Learning Organization, 19(6), 518-528. http://dx.doi.org/10.1108/09696471211266974

[33] Sutherland, M. and Jordaan, W. (2004). Factors affecting the retention of knowledge workers. SA Journal of Human Resources Management, 2, 55-64.

[34] Clark, D. (2004). Knowledge. Available http://nwlink.com/ donclark/knowledge/knowledge.html [August 5, 2011].

[35] Kaye, B. \& Jordan-Evans. (2012). what matters most? A White paper about organisational stay factors. Retrieved March, 10, 2013, from www.keepem.com

[36] Abdullah, H. (2009). Major challenges to the effective management of human resource training and development activities. Journal of International Social Research, 2(8), 11-25.

[37] Erwin, T. (2011). Five Top employee retention strategies. Retrieved 24 March, 2012, from http://www.mondaq.com/x/155322/Five Top Employee Retention Strategies

[38] Jamrog. J. (2005). The Perfect Storm: The Future of Retention and Engagement. Retrieved August, 4, 2011, from www.cmctraining.org

[39] Benest, F. (2008). Retaining and Growing Talent: Strategies to Create Organizational "Stickiness". Public Management, 90(9), 20-24.

[40] Milne, G. (2007). Motivating the knowledge worker to perform. MBA dissertation, GIBS: South Africa. Retrieved November, 2014, from http://www.mcser.org/journal/index.php/mjss/article/viewFile/5045/4874 
[41] Trevor, C.O. (2001). Interactions among actual ease-of movement determinants and job satisfaction in the prediction of voluntary turnover. Academy of Management, 44 (4), 621-638.

[42] Samuel, M. and Chipunza. C. (2009). Employee retention and turnover: Using motivational variables as a panacea. African Journal of Business Management, 3(8), 410-415.

[43] Perumal, M. (2008). Association between employee motivation and employee demographics in the banking industry. MBA dissertation, University of South Africa. Retrieved 1st December 2008, from http://uir.unisa.ac.za/bitstream/handle/10500/3166/2008;jsessionid=9BB888178331E0D3BC6E90B6 373AB 139? sequence $=1$

[44] Gaertner, S. (1999). Structural determinants of job satisfaction and organisational commitment in turnover models. Human Resource Management Review, 9 (4), 479-493.

[45] Cho, Y., \& McLean, G. N. (2009, July). Leading Asian countries' HRD practices in the IT industry: A comparative study of South Korea and India. Human Resource Development International, 12(3), 313-331.

[46] McDonnell, A. (2011). Still fighting the "war for talent"? Bridging the science versus practice gap. Journal of Business \& Psychology, 26(2), 169-173.

[47] Davenport, T. H. (2005). Improving Knowledge Worker Performance. MIT Sloan Management Review, 46(4), 215-235.

[48] Price, J.L. (1999). Introduction to the special issue on employee turnover. Human Resource Management Review, 9 (4), 387-395.

\section{AuThORS}

\section{Munish}

Munish is presently working as an assistant professor at Aravali College of Engineering \& Management, Faridabad. The author has 8 years of teaching experience in variousManagement discipline subjects. The author is presently Pursuing $\mathrm{PhD}$ from YMCA University of science \& Technology, Faridabad.

\section{Dr. Rachna Agarwal}

Dr. Rachna Agarwal is presently working as an associate professor in YMCAUST, Faridabad. He has a teaching experience of more than 13 years. She has actively involved in research area and having more than 15 research papers in national and international journals and contributed in many conferences as well.
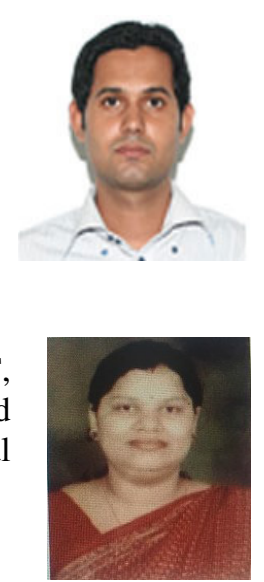